\title{
Laboratory Test Research on Collapsible Loess Foundation Treatment
}

\author{
Yan Shao $^{a, 1}$, Man Yuan ${ }^{a, 1}$, Yong Hao ${ }^{a, *}$, and Xiaohong Sun ${ }^{b}$ \\ ${ }^{a}$ College of Urban Construction, Yangtze University, Jingzhou, Hubei, 434023, China \\ ${ }^{\mathrm{b}}$ CCCC Second Navigation Engineering Survey and Design Institute Co., Ltd
}

\begin{abstract}
Combined with the Dingxi-Lintao Expressway, this paper discusses the method of strengthening the collapsible loess foundation, and conducts the indoor California Bearing Ratio (CBR) test research according to the characteristics of the highway project. Under the optimal water content, through the comparison analysis of the test results of the plain soil California Bearing Ratio test and the lime soil California Bearing Ratio test after the ash mixing ratio reaches 5\%, it can be found that under the condition that the compaction degree reaches $96 \%$, the test result after ash mixing is $5 \%$ The CBR value of this kind has been greatly improved, and the expansion amount has been drastically reduced. It is proved that this treatment method can eliminate the adverse effects of collapsible loess, significantly increase the bearing capacity of the foundation, and provide good guidance for the subsequent roadbed treatment design and construction.
\end{abstract}

\section{Chapter 1 Introduction}

In highway engineering, the collapsible loess roadbed shows obvious collapsibility after encountering water, and the bearing capacity often does not meet the design requirements, which easily causes the roadbed to settle and become unstable, which is more harmful and requires foundation treatment.

The Dingxi-Lintao Expressway is located in the west of the Longxi Loess Plateau, and loess-like soils of aeolian and alluvial origin are widely distributed along the line. According to the statistics of indoor collapsibility test results, the proportion of collapsible loess samples is $65.5 \%$. Most of the collapsible loess is self-weight collapsible loess, and the collapsibility is mostly medium to strong, which cannot meet the engineering requirements. Therefore, it is obviously very important to select an appropriate foundation treatment method to eliminate the adverse effects of collapsibility and effectively improve the bearing capacity of the roadbed.

\section{Chapter 2 Analysis of the treatment method of collapsible loess foundation}

Common treatment methods for collapsible loess foundation include replacement method, dynamic compaction method, compaction method, prepreg method $^{[1-2]}$, etc.

The replacement method usually adopts lime soil (lime and cohesive soil) or plain soil, and replaces the collapsible loess above the groundwater level on the surface (within $3 \mathrm{~m}$ ) under the optimal water content, rolls and compacts it to the design height. It can eliminate the impact of foundation collapsibility within the replacement thickness. The advantage of this method is simple construction and remarkable effect ${ }^{[3-5]}$.

The dynamic compaction method is suitable for treating collapsible loess with saturation not greater than $60 \%$. Compared with the replacement method, this method can treat a larger thickness, usually up to $12 \mathrm{~m}$. During processing, the weight is lifted to obtain a certain gravitational potential energy and then fall freely, and the soil is compacted by potential energy impact, which can effectively improve the bearing capacity of the loess and compact the soil. The advantages are economy, simplicity and fast processing speed.

The compaction method is suitable for collapsible loess above the groundwater level and saturation not greater than $65 \%$, and the treatment thickness can reach $15 \mathrm{~m}$. This method can use different processes to form holes in advance, and then use various fillers, such as plain soil, lime soil, fly ash, cement or crushed stone, to backfill and compact in layers to achieve compaction, cementation and solidification to destroy the original loess. It has loose and large pore structure to eliminate its collapsibility. The advantages are simple construction, good effect and relatively economical.

The prepreg method uses the self-weight collapsibility of the self-weight collapsible loess foundation. Before the construction of the structure, the foundation is fully immersed in water to cause it to collapse under its own weight and eliminate the self-weight collapsibility of the surface loess. This method consumes a lot of water and tends to cause the surface to crack and sink.

"Corresponding author: 518004@yangtzeu.edu.cn; ${ }^{1}$ These authors contributed equally to this work. 
In combination with the characteristics of highway subgrade projects, usually the subgrade has a shallow range of action and a long line. It is best to adopt a simple, easy, and economical shallow treatment method. Comprehensive consideration, it is planned to adopt the replacement method for processing. Most areas along the line are loess subgrades. For the convenience of construction, it is planned to consider taking local materials and using loess plain soil or lime soil as the subgrade fill. Therefore, the bearing capacity of the loess plain soil and lime soil should be measured after rolling experimental research.

\section{Chapter 3 California Bearing Ratio test and comparative analysis}

Based on the above analysis, combined with the characteristics and requirements of the highway subgrade, after sampling on-site, the California Bearing Ratio (CBR) test of plain soil and lime-mixed soil were carried out respectively. The test instrument used the CBR-1 California Bearing Ratio tester produced by Nanjing Soil Instrument Factory, as shown in Figure 1.

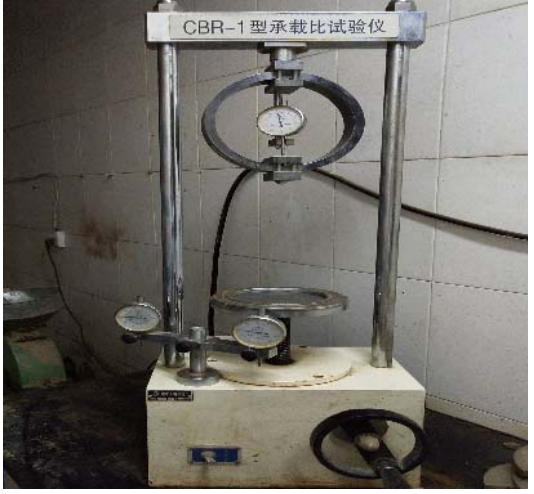

Figure 1 CBR-1 California Bearing Ratio test apparatus In this test, a total of three borrow yards were set up on the site, namely borrow yard No. 1, borrow yard No. 2 and borrow yard No. 3, and the corresponding sampling points were TL1, TL2 and TL3. First carry out a compaction test to obtain the maximum dry density and optimal moisture content. Taking the 5\% ash-mixed sample of TL3 as an example, prepare the moisture content of $11 \%, 13 \%, 15 \%, 17 \%, 19 \%$, according to the test results, it can be seen that the optimal water content is $15 \%$, the maximum dry density is $1.81 \mathrm{~g} / \mathrm{cm}^{3}$, and the compaction test results are shown in Table 1. Then, a further compaction test was carried out under the optimal water content, and the degree of compaction was measured. The results are shown in Table 2. While, the corresponding samples in Table 2 were subjected to the California Bearing Ratio tests, and the unit pressure and penetration curve results are shown in Figures 2 to 4 .

Table 1 Results of compaction test

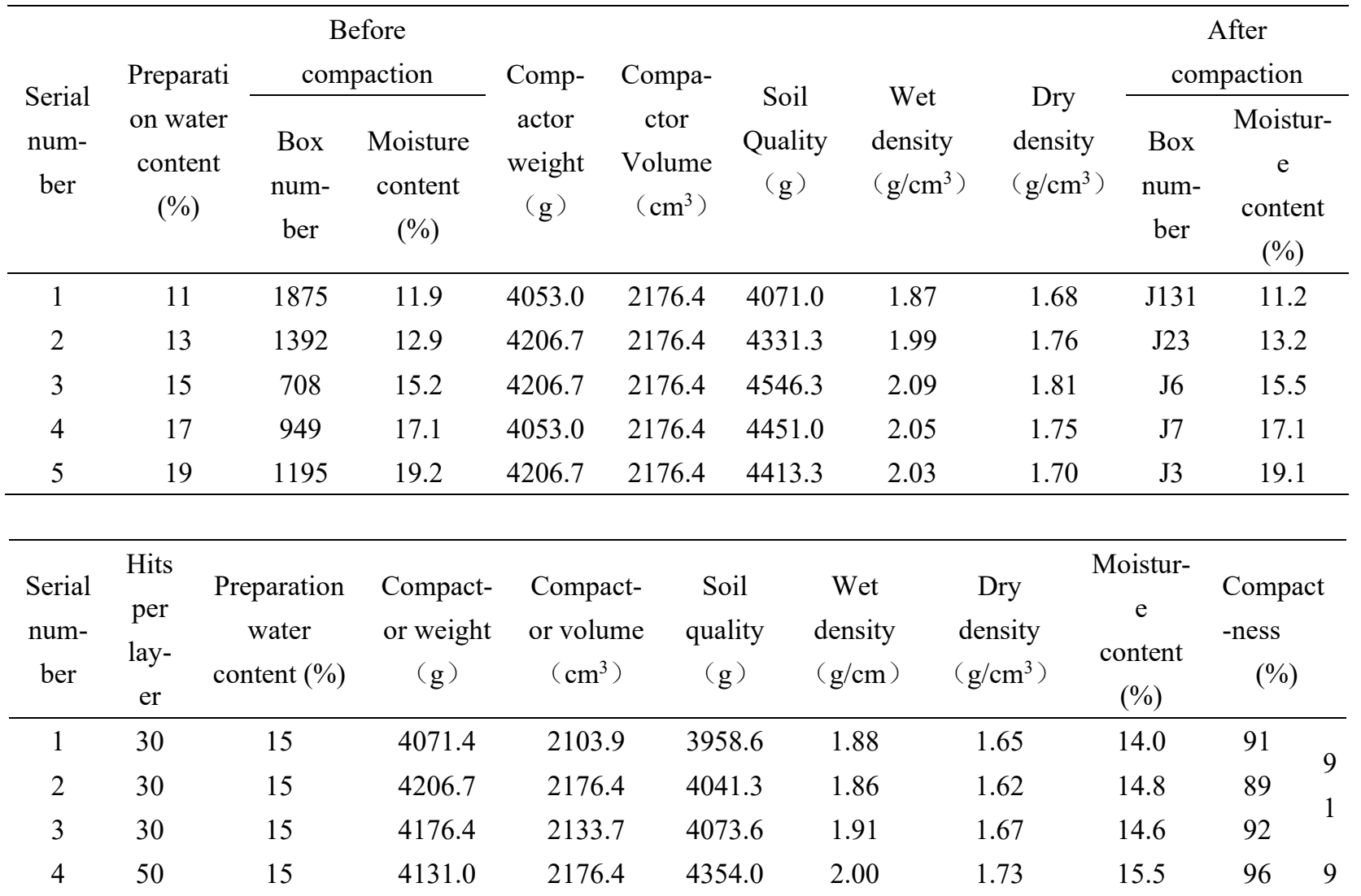




\begin{tabular}{ccccccccccc}
5 & 50 & 15 & 4131.8 & 2176.4 & 4240.2 & 1.95 & 1.71 & 14.2 & 94 & 5 \\
6 & 50 & 15 & 4174.0 & 2165.8 & 4265.0 & 1.97 & 1.72 & 14.4 & 95 & \\
7 & 98 & 15 & 4091.2 & 2176.4 & 4480.8 & 2.06 & 1.80 & 14.3 & 100 & \\
8 & 98 & 15 & 4253.0 & 2176.4 & 4426.0 & 2.03 & 1.78 & 14.5 & 98 & 9 \\
9 & 98 & 15 & 4037.0 & 2176.4 & 4483.0 & 2.06 & 1.80 & 14.2 & 100 & 9 \\
\hline
\end{tabular}

Table 2 Compaction test results under optimal water content
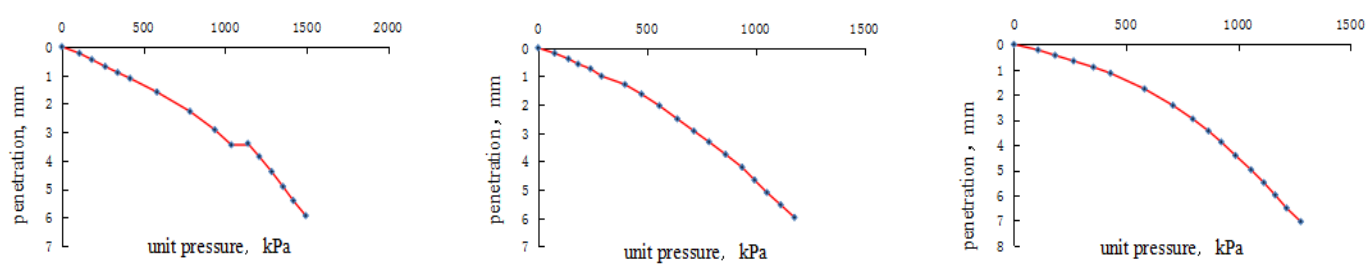

Figure 2 Curve of unit pressure and penetration (30 hits)
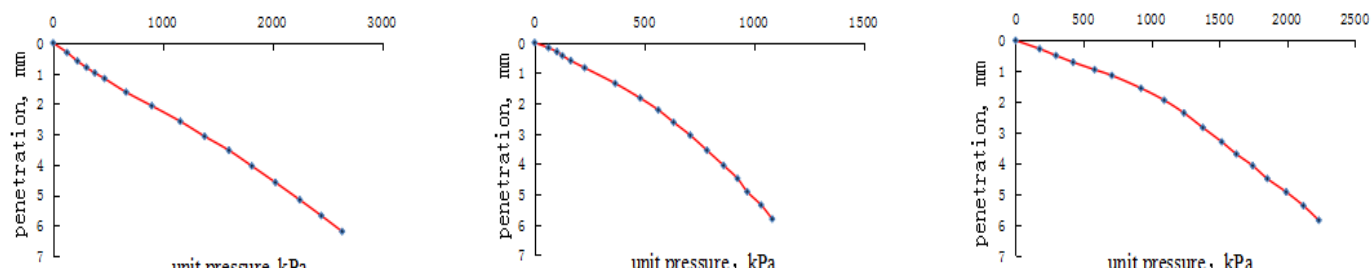

Figure 3 Curve of unit pressure and penetration (50 hits)
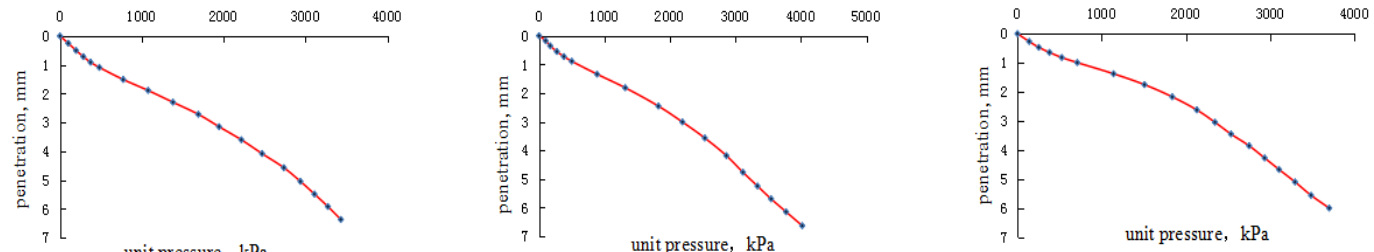

Figure 4 Curve of unit pressure and penetration (98 hits)

According to the above test, the California Bearing Ratio results of the corresponding samples can be obtained. As shown in Table 3, the average dry density and the average California Bearing Ratio of each set of data are obtained, and the dry density and CBR curves are drawn according to the test results. It can be calculated that the corresponding CBR value is $22.6 \%$ when the degree of compaction is $96 \%$, as shown in Figure 5.

Table 3 Test results of California Bearing Ratio (CBR) of 5\% sample with ash

\begin{tabular}{lcccccccccc}
\hline compactness (\%) & \multicolumn{3}{c}{91} & \multicolumn{3}{c}{95} & \multicolumn{3}{c}{99} \\
\hline Number of compactions & \multicolumn{2}{c}{30} & & & 50 & & & 98 \\
\hline Tube number & 10 & 9 & 19 & 16 & 4 & 23 & 5 & 2 & 1 \\
Wet density $\left(\mathrm{g} / \mathrm{cm}^{3}\right)$ & 1.882 & 1.86 & 1.91 & 2.00 & 1.95 & 1.97 & 2.06 & 2.03 & 2.06 \\
Measured water content (\%) & 14.0 & 14.8 & 14.6 & 15.5 & 14.2 & 14.4 & 14.3 & 14.5 & 14.2 \\
Dry density $\left(\mathrm{g} / \mathrm{cm}^{3}\right)$ & 1.65 & 1.62 & 1.67 & 1.73 & 1.71 & 1.72 & 1.80 & 1.78 & 1.80 \\
Average dry density $\left(\mathrm{g} / \mathrm{cm}^{3}\right)$ & & 1.645 & & & 1.717 & & & 1.794 & \\
California Bearing Ratio (\%) & $13.0^{*}$ & 9.9 & 10.1 & 20.9 & $9.3 *$ & 19.2 & 27.8 & 30.7 & 30.9 \\
Average California Bearing Ratio(\%) & & 10.0 & & & 20.1 & & & 29.8 & \\
\hline
\end{tabular}

Note: * is the larger value of the discrete, not included in statistics. 


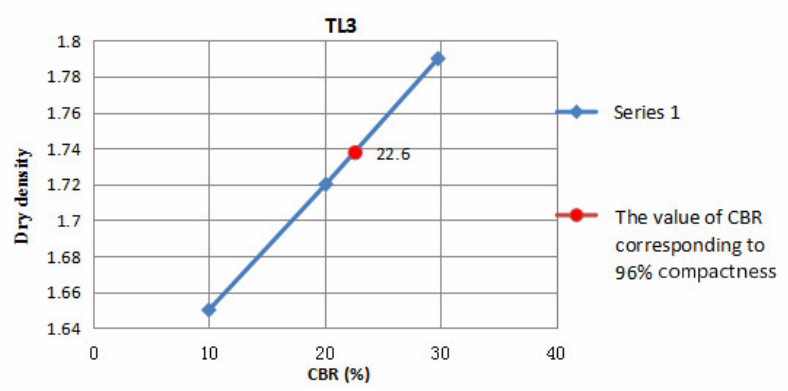

Figure 5 CBR value at $96 \%$ compactness

The above test data is based on the compaction and California Bearing Ratio test results of the 5\% ash-doped sample at the sampling point of TL3 as an example. In the same way, after testing the plain soil samples at TL3 sampling points and comparing the test results of multiple samples of plain soil samples at TL1 and TL2 and their respective samples mixed with $5 \%$ ash, we can find the collapsibility along the site The lime soil formed after the loess is mixed with $5 \%$ ash has been compacted in layers under the optimal moisture content, and its bearing capacity has been greatly improved compared with plain soil. The comparison results of each group of data are shown in Table 4.

The above comparison results show that compared with plain soil, the optimal water content of lime soil increases, and the maximum dry density decreases. At a compaction degree of $96 \%$, the California Bearing Ratio CBR value of lime soil is about 3.9 5.0 times higher than that of plain soil. The amount is reduced to $19 \% \sim 24 \%$ of the plain soil. It can be seen that the bearing capacity of the soil is greatly improved after 5\% ash mixing, and the stability is significantly enhanced.

\section{Chapter 4 Conclusion}

In view of the collapsible loess subgrade, considering the characteristics of highway engineering, the replacement method can be used to treat the surface loess. According to the results of laboratory tests, compared with plain soil, the load-bearing capacity of lime soil mixed with $5 \%$ lime under the optimal moisture content and $96 \%$ compactness is increased by about 3.9 5.0 times, and it expands. The amount drops sharply and the stability is obviously enhanced. The design and construction of the subsequent collapsible loess foundation treatment of the line can be used as a reference.

Table 4 Comparison of compaction and California Bearing Ratio test of plain soil and lime soil

\begin{tabular}{|c|c|c|c|c|c|c|c|c|c|c|}
\hline \multirow{2}{*}{$\begin{array}{l}\text { Num } \\
\text {-beri } \\
\text { ng }\end{array}$} & \multirow[b]{2}{*}{$\begin{array}{l}\text { Locati- } \\
\text { on }\end{array}$} & \multirow{2}{*}{$\begin{array}{l}\text { Ash } \\
\text { mixi- } \\
\text { ng } \\
\text { ratio }\end{array}$} & \multicolumn{2}{|c|}{ Compaction test } & \multirow{2}{*}{$\begin{array}{l}\text { Measured } \\
\text { Compact- } \\
\text { ness }\end{array}$} & \multicolumn{2}{|c|}{$\begin{array}{l}\text { California } \\
\text { Bearing Ratio } \\
\text { test }\end{array}$} & \multirow{2}{*}{$\begin{array}{c}\text { Requi- } \\
\text { red }\end{array}$} & \multicolumn{2}{|c|}{$\begin{array}{c}\text { California Bearing } \\
\text { Ratio test }\end{array}$} \\
\hline & & & $\begin{array}{c}\text { Optimal } \\
\text { water } \\
\text { content } \\
(\%)\end{array}$ & $\begin{array}{l}\text { Maxim- } \\
\text { um dry } \\
\text { density } \\
\left(\mathrm{g} / \mathrm{cm}^{3}\right)\end{array}$ & & CBR & $\begin{array}{c}\text { Expans- } \\
\text { ion } \\
(\%)\end{array}$ & & $(\%)$ & Expansion \\
\hline & No. 1 & & 13.5 & 1.84 & $86 \%$ & 2.2 & 2.96 & & & \\
\hline TL1 & borrow & & & & $90 \%$ & 4.6 & 3.11 & $96 \%$ & 7.6 & 2.91 \\
\hline & yard & & & & $100 \%$ & 12.5 & 2.64 & & & \\
\hline & No. 1 & & 17.0 & 1.76 & $90 \%$ & 11.8 & 0.49 & & & \\
\hline TL1 & borrow & $5 \%$ & & & $93 \%$ & 21.0 & 0.44 & $96 \%$ & 30.2 & 0.58 \\
\hline & yard & & & & $98 \%$ & 38.5 & 0.80 & & & \\
\hline & No. 2 & & 12.2 & 1.95 & $91 \%$ & 3.2 & 2.85 & & & \\
\hline TL2 & borrow & & & & $95 \%$ & 5.1 & 3.02 & $96 \%$ & 5.9 & 2.82 \\
\hline & yard & & & & $100 \%$ & 11.1 & 2.58 & & & \\
\hline & No. 2 & & 15.9 & 1.84 & $91 \%$ & 11.6 & 0.69 & & & \\
\hline TL2 & borrow & $5 \%$ & & & $94 \%$ & 23.0 & 0.74 & $96 \%$ & 29.8 & 0.68 \\
\hline & yard & & & & $99 \%$ & 46.2 & 0.60 & & & \\
\hline & No. 3 & & 12.7 & 1.88 & $91 \%$ & 3.2 & 3.34 & & & \\
\hline TL3 & borrow & & & & $96 \%$ & 5.9 & 3.20 & $96 \%$ & 5.8 & 3.31 \\
\hline & yard & & & & $100 \%$ & 11.7 & 3.40 & & & \\
\hline TL3 & No. 3 & $5 \%$ & 15.0 & 1.81 & $91 \%$ & 10.0 & 0.81 & $96 \%$ & 22.6 & 0.70 \\
\hline
\end{tabular}




\begin{tabular}{clll} 
borrow & $95 \%$ & 20.1 & 0.65 \\
yard & $99 \%$ & 29.8 & 0.63 \\
\hline
\end{tabular}

\section{References}

1. J. Wu, W. Gu, Z. Chen. Experimental Study on THE CBR value of loess Subgrade [J].Traffic and Transportation Research, 2,125-127(2005)

2. K. Yuan, J. Dang, L. Zhuo, Study on factors influencing THE CBR value of loess Subgrade [J].Subgrade Engineering, 6,125-127(2009)

3. Z. Feng, Y. Xie. Theoretical calculation of the optimal moisture content and maximum dry density in standard compaction Test[J]. Journal of Chang'an University (Natural Science Edition), 2,10-13(2002)

4. Y. Zhou. Experimental Study on Treatment of Collapsible Loess Subgrade Based on Lime-soil Cushion Method[J].Inner Mongolia Science Technology and Economy, 18,64-65(2009)

5. W. Zhang. Treating the foundation of collapsible loess area with plain soil and lime soil Cushion[J]. Gansu Science and Technology, 11,114-115(2009) 